\title{
Regulation of the Warsaw Stock Exchange: History and Operating Rules
}

\author{
Joanna Małecka \\ Poznan University of Technology, Poznan, Poland
}

\begin{abstract}
The aim of this article is to present the principles of the operation of the Warsaw Stock Exchange (WSE), which is the most important institution of the capital market in Poland. The article is an attempt to explore the history and structure of the exchange and its investment possibilities in order to understand the number of existing security features which make cooperation with this institution-with appropriate assumptions and diversification-an activity providing profits to potential investors who are aware of its operating rules. This topic deserves a historical outline because of the socialist past and the current status of the WSE, now called the most dynamically growing capital market in Central and Eastern Europe.
\end{abstract}

Keywords: stock exchange, WSE, regulation, main market, secondary market, NewConnect

\section{Introduction}

The capital market represents one of the essential components of the economy. Having capital means development, which involves possibilities of adapting to the rapidly changing market economy (Łuczka, 2013; Milewski, 1998, p. 305; Modigliani \& Miller, 1958). Its most important function is the ability to raise capital for development for both entrepreneurs who are directly connected to the offered possibilities and potential investors (Myers, 1983, pp. 575-592; Robinson, 1958, p. 161). In this way, funds that remain available in the economy do not go to bank accounts, and are used to invest in the development of the most promising industries which through mandatory presentations to potential investors present valuations recognized as credible and reliable. Why, then, do Poles still prefer to make deposits in banks rather than to start collecting capital for the future through the stock exchange? A reason for this may be the stereotype of the risk of rapid bankruptcy (Altman, 1968; 2000; Altman \& Hotchkiss, 2005; Gajdka \& Stos, 1996). Nevertheless, it can easily be argued that a more important obstacle may be the lack of knowledge on how the stock exchange operates, its organization and the competence of the people who verify each security to be issued. The article presents the history of the stock exchange along with its basic structure and all existing regulations which form the criteria for valuation of securities and safety of the offered stock exchange transactions (see: Bień, 2008; Czapkiewicz \& Wojtowicz, 2014, pp. 771-783; Flores \& Szafarz, 1997; Nawrocki \& Jabłoński, 2011; Perz, 2008).

It can easily be argued that in Poland the knowledge of the capital market is not popularized among both potential investors and issuers not only in the sector of small- and medium-sized enterprises but also in that of individual investors (CSO, 2015). In Poland, more than 50\% of gross domestic product (GDP) is generated by

Joanna Małecka, M.Sc., Faculty of Engineering Management, Poznan University of Technology, Poznan, Poland.

Correspondence concerning this article should be addressed to Joanna Małecka, Strzelecka 11, 60-956 Poznan, Poland. 
SMEs, which only confirms compliance with the statistics that are currently achieved in the EU-28 (www.ec.europa.eu/eurostat, 02.26.2016). It is worth emphasizing, however, that among over 1.8 million companies in Poland, 1.7 million are micro-, small-, and medium-sized enterprises of which 1.65 million are micro-entrepreneurs (CSO, 2013; 2014) that do not fully benefit from the capital market possibilities. This is evidenced by the level of taking advantage of opportunities for development offered by the capital market through private equity programs, such as start-up, seed, and venture capital, that allow for raising development capital through the stock exchange as a consequence of purchase options (Metrick \& Yasuda, 2011, pp. 619-654; Vanacker \& Manigart, 2013).

In order for the economy to grow both domestically and globally, capital must flow properly through an appropriately operating public capital market which, in turn, is guaranteed by a properly functioning stock exchange (Płókarz, 2013; Gilson \& Black, 1998). Companies that want to make full use of the capital market, in particular the Initial Public Offering (IPO), should be aware of one of major elements enabling cooperation with the stock exchange, namely, survival in the market (Łuczka, 2015, pp. 86-97; Małecka, 2015a, pp. 496-507; 2015b, pp. 39-54). This holds true for both the IPO market and NewConnect (Kordela, 2013). That is why it is so important for innovative entrepreneurs who can clearly specify business goals and precisely define their strategies to be able to learn how the capital market tools (start-up, IPO, Venture Capital, as well as business angels programs and corporate venturing) work (Da Gbadji, Gailly, \& Schwienbacher, 2015, pp. 1213-1245; Gompers \& Lerner, 2001, pp. 145-168; Gilson \& Black, 1998, pp. 243-277), as those tools are a source of financing that is alternative to traditional forms of the money market (credits, loans, leasing, and factoring) (Bielawska, 2001; 2005, pp. 437-447; Łuczka, 2013; 2015, pp. 86-97). The article is an attempt to outline clearly the history of the Polish capital market, the principles of the stock exchange shareholding construction and market structure in order to popularize the WSE as an alternative source of development capital.

\section{History of the Formation of the Warsaw Stock Exchange}

The first stock exchange in Poland was established by decree of the Prince Viceroy of the Kingdom of Poland on May 12, 1817 as the Mercantile Exchange, which ran its operations in the Saxon Palace until the start of World War II ${ }^{1}$. The sessions took place from 12:00 to 13:00, with mainly bills and bonds being traded. In 1945, there was an attempt to revive it; however, it was fruitless, because it was impossible to reconcile its principles with the system of a centrally planned economy.

It was not until April 16, 1991 that on the fifth floor of the former building of the Central Committee of the Polish United Workers' Party, the first listing on the WSE took place ${ }^{2}$. Preparations for the first session were ongoing at the same time as renovations, which had to be suspended for the historical opening when the shares of five companies were listed: Tonsil, Exbud, Krosno, Kable, and Próchnik. The first sessions were held once a week. Stock prices were established on the basis of orders received on paper by employees of the exchange, and all calculations were made on calculators. The following year, on January 9, the second trading session was introduced, and on January 4, 1993 another one. The number of companies on the stock market

\footnotetext{
${ }^{1}$ During the interwar period, there were also stock exchanges in Krakow, Katowice, Lvov, Lodz, Poznan, and Vilnius, which operated on the basis of the President's decree on the organization of exchanges.

${ }^{2}$ On 12.04.1991 the instrument of incorporation of the Warsaw Stock Exchange was signed, and the official opening took place on 02.07.1991.
} 
quadrupled during that time, and the trading in government bonds began. Stock quotes could then be checked using teletext on the Polish public TV. The WSE established contacts with the World Federation of Exchanges and the Federation of European Securities Exchanges. On April 22, 1993, the second trading floor was launched which was designed for smaller businesses that did not meet all the requirements of admission to the stock market - the parallel market.

The years 1994-1999 brought many dynamic changes on the WSE. On April 16, 1994, the WIG20 index (index of the largest companies) was established, real-time broadcast of post-auction trading was launched over teletext, and the fourth ${ }^{3}$ and the fifth ${ }^{4}$ sessions during the week were also introduced. The parallel market index WIRR (currently sWIG80) was set up on January 3, 1995, and the first five companies began trading on a continuous basis in $1996^{5}$. After the privatization that commenced in 1994, in 1997 the 100th company was listed on the stock market, and by the end of 1999, there were over 200 companies listed ${ }^{6}$.

In 2000, work on the introduction of a modern computer system was being finalized. Quotes were then released to the public in real time over the Internet, and on November 17, the new trading system Warset was implemented. The SiTech segment was also created (for innovative-technology companies), and the new TechWIG index was defined for them. In 2001, the WSE began cooperation with the Lithuanian National Stock Exchange, and on October 14, 2003, the first foreign company had its debut-Bank Austria Creditanstalt AG.

In later years, thanks to the establishment of firm development measures, the following investment instruments were launched: futures, corporate bonds, options, warrants, and ability to open short positions. In 2005, the WSE began operations involving the first remote member of the stock exchange ${ }^{7}$ and signed an agreement with the first participant of the WSE IPO Partner program ${ }^{8}$. In 2007, after a wave of a two-year bull market, information on granting Poland and Ukraine the hosting of Euro 2012 caused the WIG index to reach 65 thousand points. From March 1, 2007, new indices were introduced: WIG40 and sWIG80. A month later, there was a new segmentation on the regulated market: Five Plus, 50 Plus, 250 Plus, and on August 30 the alternative trading system NewConnect started operating.

On September 30, 2009, a system of authorization and trading in non-treasury debt instruments known as Catalyst was founded. It was designed for both the retail market, currently operated through two of the four platforms of the WSE (in the form of the regulated market and the alternative trading system), and the wholesale market, which is operated by BondSpot (formerly MTS CeTO). These platforms are intended for debt instruments (treasury and non-treasury). The purpose of their formation was to attract investors seeking with a moderate level of risk - projects with high profitability. More convenient procedures were to encourage companies to issue bonds. Through the issue, authorization, and quotation of corporate bonds, that form of trading was deemed safe, with transparent finances and moderate risk. Since April 15, 2013, the WSE has executed transactions based on the UTP system, which meets the highest global standards, is highly efficient, scalable, and fast, enabling the operation of tens of times more orders per unit of time ${ }^{9}$. Thanks to UTP, the WSE has a chance to encourage the investment of large global investment firms using algorithmic trading

\footnotetext{
301.07 .1994$.

403.10 .1994$.

5 08.07.1996.

${ }^{6}$ Skotan-the two-hundredth company on the WSE, 11.01.1999.

7 11.07.2005, Fischer Partners Fondkommission AB.

8 06.11.2006, Ukrainian brokerage house based in Kiev E-volution Capital.

${ }^{9}$ Comparing results: Warset: 850-UTP: 20 thousand orders per second.
} 
techniques which already constitute $40 \%-60 \%$ of the total turnover globally.

Formally, since November 9, 2010, the WSE has been a joint stock company with the majority share of the State Treasury. Its shareholders are also banks and brokerage firms; however, the law also allows other shareholders (Figure 1).

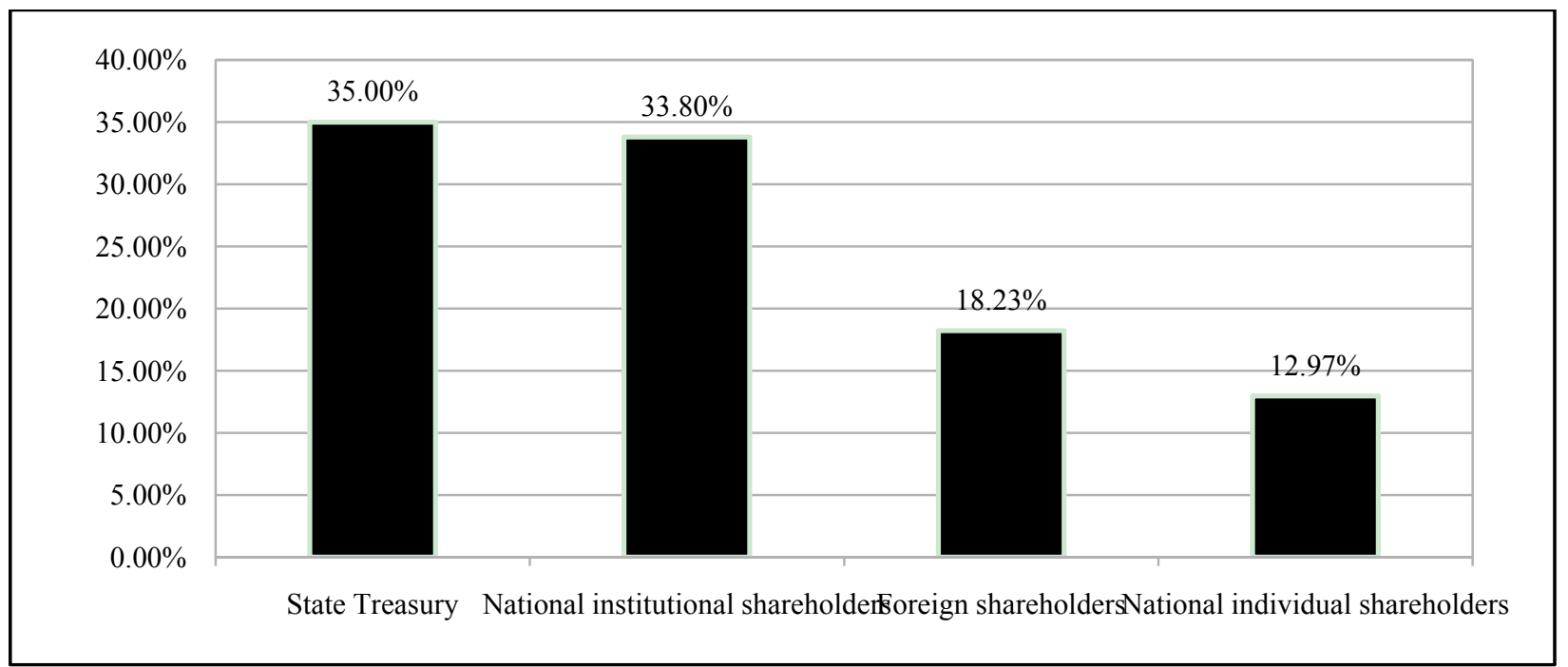

Figure 1. Structure of shareholders according to the proportion of the number of shares-as of 07.08.2014. Source:

Own preparation on the basis of WSE data.

Currently, the Treasury still holds $35 \%$ of preferred shares and other shareholders hold $0.22 \%$ of preferred shares and $64.79 \%$ of bearer shares (free float) (https://www.gpw.pl/akcjonariat, 27.02.2016).

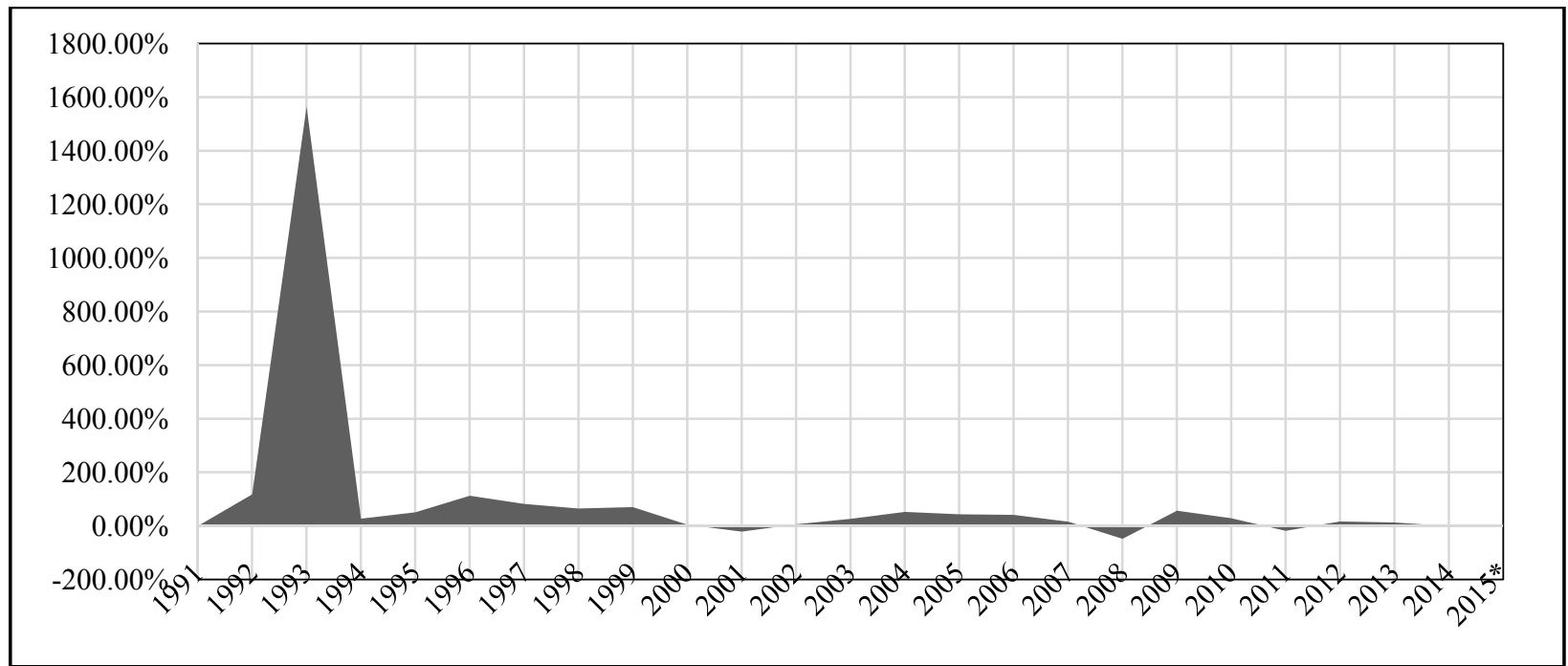

Figure 2. Dynamics of capitalization of domestic companies (million PLN). Note. * Data from March 2015. Source: Own preparation on the basis of WSE data.

The activity of the stock exchange is regulated by the following acts: Code of Commercial Companies, Act on Trading in Financial Instruments, Statues of the WSE, Rules of the WSE (https://www.gpw. pl/pub/files/PDF/regulacje/regulamin-gpw.pdf, 27.02.2016), Detailed Exchange Trading Rules, and Rules of the Stock Exchange Court. According to data from February 26, 2016, the number of companies listed on the 
WSE is 433, of which 390 (including 344 domestic, 46 foreign) are on the primary market and 96 on the parallel market (including 89 domestic, seven foreign). Their total capitalization value is PLN 968,613 million. The results of dynamic capitalization of domestic companies as well as shares and bonds trading are presented in Figures 2 and 3. Fluctuations in the rate of return in 1999-2015 are shown in Table 1, which clearly depict the nature of the stock exchange as a long-term investment instrument (Mrzygłód \& Nowak, 2013, pp. 111-123; Bień, 2008; Dębski, 2014).

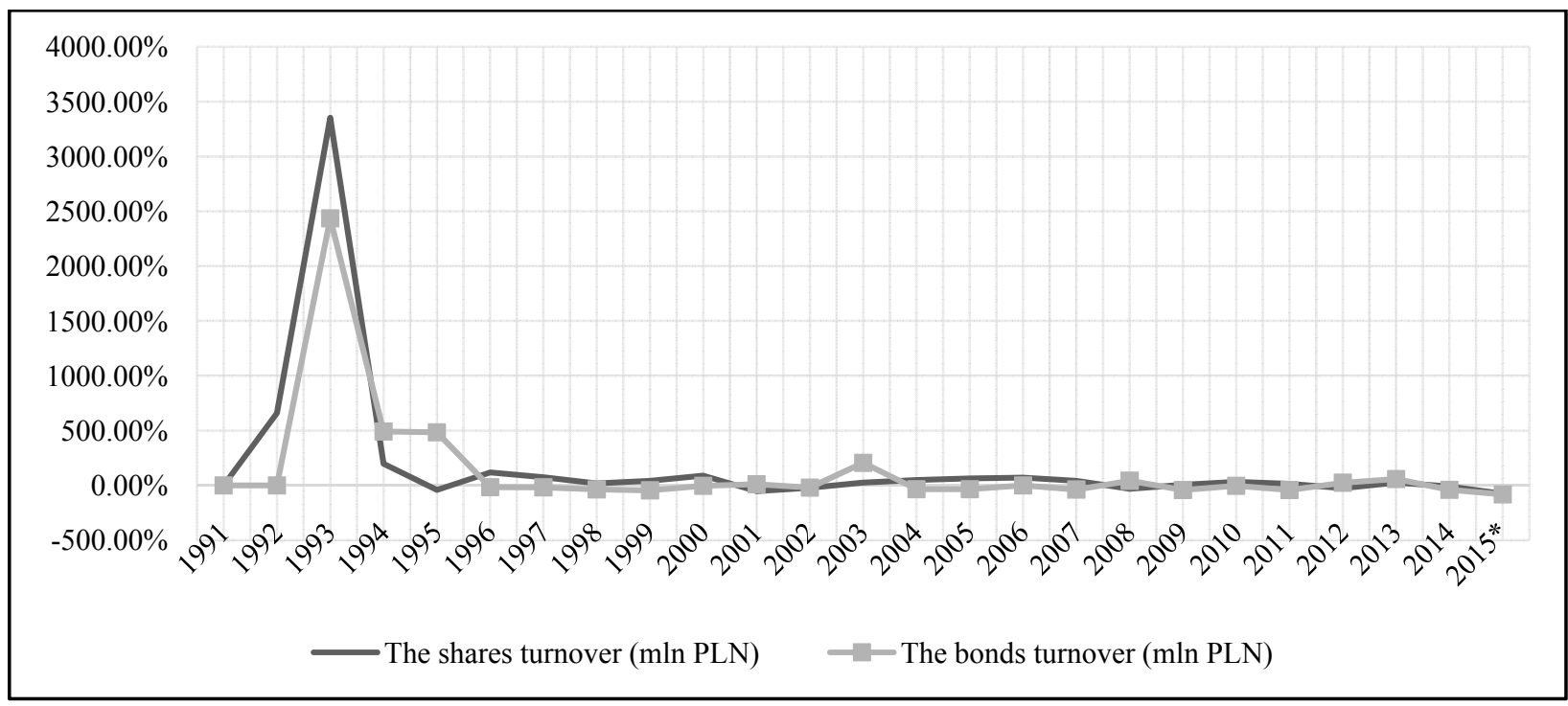

Figure 3. Dynamics of trading in stocks and bonds (million PLN). Note. * Data from March 2015. Source: Own preparation on the basis of WSE data.

Table 1

WIG's Rate of Return in 1991-2015 (\%)

\begin{tabular}{lllllllllll}
\hline Year & 1991 & 1992 & 1993 & 1994 & 1995 & 1996 & 1997 & 1998 & 1999 & 2000 \\
\hline WIG & -8.09 & 13.20 & $1,095.30$ & -39.90 & 1.50 & 89.10 & 2.30 & -12.80 & 41.30 & -1.30 \\
\hline Year & 2001 & 2002 & 2003 & 2004 & 2005 & 2006 & 2007 & 2008 & 2009 & 2010 \\
\hline WIG & -21.99 & 3.19 & 44.92 & 27.94 & 33.66 & 41.60 & 10.39 & -51.07 & 46.85 & 18.77 \\
\hline Year & 2011 & 2012 & 2013 & 2014 & $2015^{*}$ & \multirow{2}{*}{$*$ Data from March 2015} & & & \\
\hline WIG & -20.83 & 26.24 & 8.06 & 0.26 & 5.20 & & & & \\
\hline
\end{tabular}

Source: Own preparation on the basis of WSE data.

\section{Principles of Operation of the Warsaw Stock Exchange}

The WSE, like any joint stock company, has management authorities: the General Meeting of the Exchange, the Exchange Supervisory Board, and the Exchange Management Board. It holds shares in other companies whose main activity is trading in securities ${ }^{10}$ and symbolic shares in other global exchanges ${ }^{11}$. The ongoing activities of the WSE are directed by the Management Board, which, among other things: admits securities to be traded, sets the rules for admitting securities to be listed, and supervises the activities of brokers and exchange members carried out on the stock exchange. The WSE operates based on three main and

\footnotetext{
${ }^{10}$ i.a: Central Securities Depository in Poland, KDPW-CCP, Exchange Centre, Aquis Exchange Ltd.

11 INNEX PJSC (10\%) and S.C. SIBEX (1.3\%).
} 
fundamental principles (Journal of Laws, 1991):

- principle of concentration of supply and demand, through providing liquidity of traded securities ${ }^{12}$;

- principle of safe and efficient transactions and settlements, so that the transaction is liquid and accessible at any time;

- principle of providing key information to assess the current value of securities admitted to trading.

Each time, the Management Board carries out a detailed analysis of the financial condition of companies that are contenders to the status of listed companies, performing an audit, checking their liquidity and their debt level (also evaluating the way in which they are financed), and assessing their presented strategies and investment plans for the coming years, as well as the experience and qualifications of the management of companies wishing to issue securities (stocks, bonds) or other financial instruments (options, futures). Such a firm and strict selection ensures safety of future transactions for both investors and companies already functioning in the exchange. Of course, everyone takes their own risk, but on the basis of data which, as presented above, are reviewed and classified by qualified and competent bodies specially formed for this purpose. Although stocks do not guarantee even a minimum rate of return, or will not provide as much liquidity as banks, the profits that are possible to achieve thanks to them are disproportionately higher than those available on other financial markets. However, to have satisfaction from these activities, one must first decide to invest. Then, liquidity and instant access to cash will not constitute the most important selection criteria, and the benefits assumed should be converted into initial capital, investment time, and portfolio diversification of purchased securities (Nawrocki \& Jabłoński, 2011; Perz, 2008; Płókarz, 2013).

\section{The Market Structure of the Warsaw Stock Exchange}

As in any modern economy, the Polish financial market consists of the money market, capital market, futures market, and other financial market segments (Małecka, 2015c, p. 351). The stock exchange forming part of the capital market may be divided into two main segments: regulated market and alternative trading system (ATS) (Figure 1). The WSE mainly includes two market systems: the main market and parallel market, and since August 30, 2007, the NewConnect platform has been operating as part of the alternative trading system.

The main market is the market which, in accordance with the Rules of the Stock Exchange (https://www.gpw.pl/pub/files/PDF/regulacje/regulamin-gpw.pdf), lists the shares of companies that meet, among others, the following criteria:

- have prepared a relevant information document concerning their activity which was approved by a competent supervisory authority, the so-called prospectus ${ }^{13}$;

- they are not subject to any bankruptcy or liquidation proceedings;

- marketability of their shares is not limited;

- all of the issued shares of a given kind are covered by the application for admission to trading;

- value of the shares covered by the application or the issuer's equity in PLN is equivalent to at least EUR five million;

\footnotetext{
12 The purpose of the exchange is, in fact, to ensure, through the available financial instruments, the greatest turnover rather than getting the highest quotes. A focus on maximizing quotes would result in record performance, but would also make transactions impossible for most investors, especially with the desire to popularize the stock market, which at that point would cease to make the market available for the meeting of buyers and sellers, creating a market available only to the financial elite instead.

${ }^{13}$ In some cases, the preparation and approval of such a document is not required. This obligation does not apply to securities issued by the State Treasury, the National Bank of Poland and some non-equity securities issued by certain groups of issuers.
} 
- shares covered by the application held by shareholders each of whom has no more than $5 \%$ of the total number of votes at the general meeting;

- represent at least $15 \%$ of all company shares or there are at least 100 thousand shares with a total value in PLN equivalent to at least EUR one million, calculated according to the last sale or issue price;

- the issuer published financial statements together with the opinion of the entity authorized to audit (the auditor) for at least three consecutive financial years preceding the application for admission to trading of shares or the company has publicly disclosed information to enable potential investors to assess its financial and economic situation as well as risks associated with the acquisition of company shares being the subject of the application.

Preparations for the initial public offering (IPO) may be undertaken only by companies with the status of joint-stock companies or limited joint-stock companies, which are required to carry out detailed financial analyses and define specific parameters of the issue of shares. Increased clarity, the introduction of corporate governance and financial transparency decisively affect credibility and market valuation of the company, which the future investor can easily find and evaluate (Mikołajek-Gocejna, 2008; Abdou \& Dicle, 2007, pp. 63-89; Ritter \& Welch, 2002, pp. 1795-1828).

The parallel market is determined by less stringent requirements due to the fact that it is dedicated mainly to smaller companies that clearly are not able to meet the accepted criteria for admission to the main market. In this way, the WSE invites companies from the small- and medium-sized enterprises sector to raise capital for development (Bień, 2008; Kołosowska, 2013). Potential issuers should meet conditions such as:

- have prepared a relevant information document concerning their activity, which was approved by a competent supervisory authority;

- they are not subject to any bankruptcy or liquidation proceedings;

- marketability of their shares is not limited.

There are three segmentations of all companies based on the criterion of the size of a company's market capitalization which is calculated as the arithmetic average capitalization in the last three months:

- five PLUS segment - includes securities of companies whose market capitalization does not exceed EUR 50 million;

- 50 PLUS segment-includes securities of companies whose market capitalization is within the range of EUR 50 to 250 million;

- 250 PLUS segment —includes securities of companies with market capitalization over 250 million.

As already mentioned, NewConnect is part of an organized market operated by the WSE outside the regulated market as an alternative trading system. The market is dedicated to small- and medium-sized enterprises operating in the sectors of new technologies, electronic media, biotechnology, alternative energy sources, etc., whose business is based primarily on intangible assets ${ }^{14}$. More favorable conditions such as private issue of shares and lack of a requirement to draw up a prospectus or to provide additional information have resulted in this form of financing having become more attractive ${ }^{15}$. Companies listed on NewConnect are

\footnotetext{
${ }^{14}$ It is not a prerequisite for debuting on NewConnect (they may be companies from other sectors, interested in obtaining sources of financing through the stock exchange, that do not meet all the requirements of the main market).

15 The most important features include: 1. no obligation to submit quarterly reports; 2. possibility to submit semi-annual reports without an audit and include only selected information; and 3. freedom of choice of accounting standards from among those recognized internationally or those that are appropriate for the company's headquarters.
} 
obliged to fulfill many criteria such as, among others:

- preparation and presentation of current reports;

- preparation and presentation of annual reports, verified by auditors;

- compliance with the principles of corporate governance.

In the alternative trading system, the following financial instruments are allowed: dematerialized shares, rights to shares and pre-emptive rights, depositary receipts, bonds ${ }^{16}$, other debt instruments, and securities issued on the basis of relevant provisions of the Polish or foreign law that have been released to the market (Kordela, 2013; Kołosowska, 2013; Mosionek-Szweda, 2014, pp. 87-105).

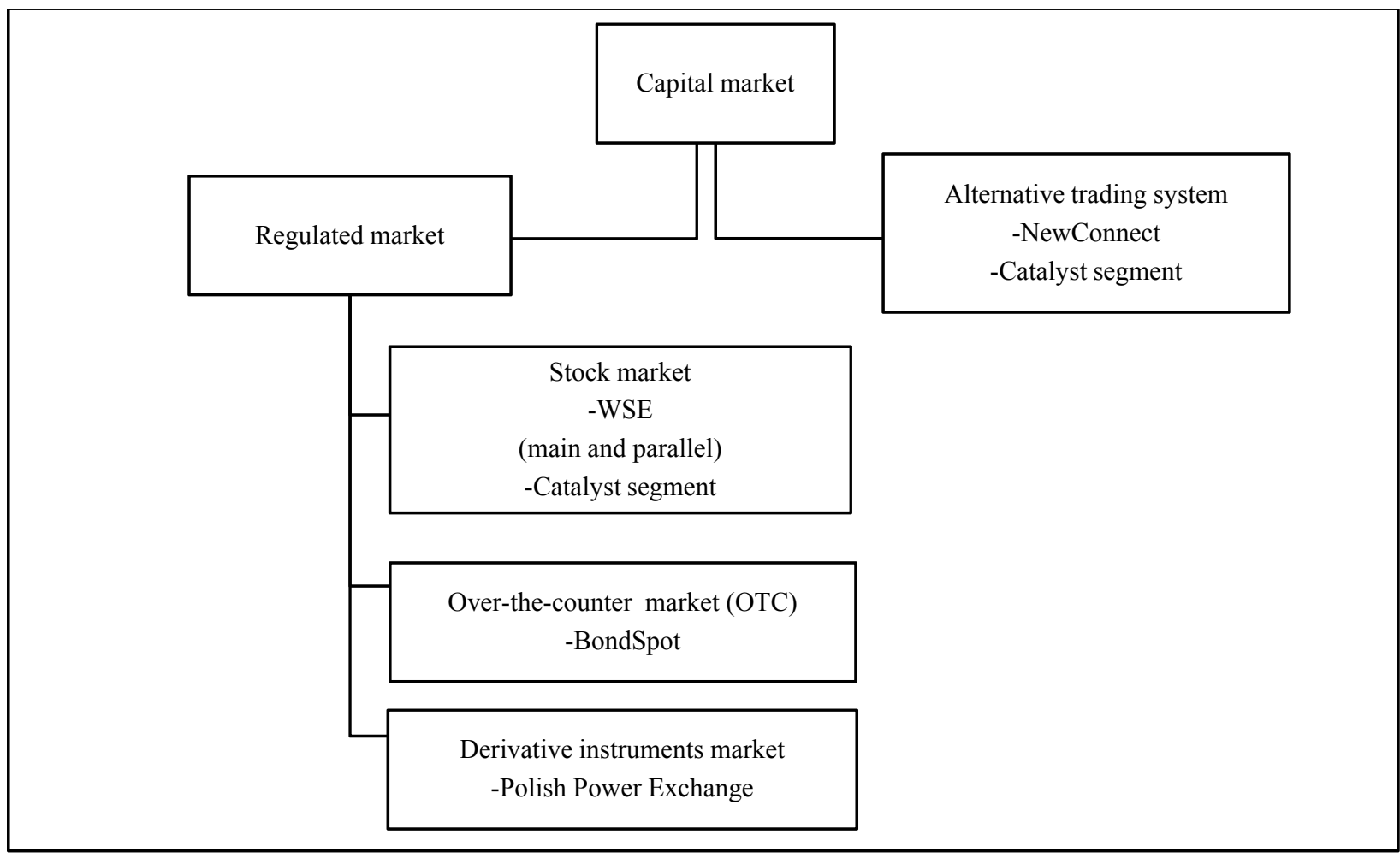

Figure 4. Structure of the capital market in Poland. Source: Own preparation on the basis of WSE data.

\section{Conclusion}

The emergence of new, highly competitive solutions on financial markets led to a situation where financial instruments that are traded belong to various market segments, not only to the capital market, but generally to the financial market. The appropriate infrastructure developed by brokerage houses, the stock exchange, and accounting systems offers increasingly wide possibilities of action. Instruments listed on the stock market may be traded on OTC markets, and in the regulated market, instruments not covered by capital market regulations may be dealt in. The possibilities offered by MTFs provide further proposals for the development of alternative trading platforms. Many of these concepts may be difficult and complicated for potential investors all the more so that precise public information includes elements of mathematical analysis and more detailed legal conditions. In consequence, this results in an even greater alienation of the market, which should contribute to an increased transparency of economic activity. In addition, banks characterized by higher liquidity (own funds

\footnotetext{
${ }^{16}$ Not applicable to bonds issued by the State Treasury and the National Bank of Poland.
} 
collected on deposit accounts can be disposed of without restrictions) and variety of offered products (credit cards, investment funds, certificates of deposit, insurance, etc.), constantly increase the attractiveness of bank deposits. The scale of their constant presence, through various ATL and BTL advertisements encountered at every step, is incomparable to the promotion of the exchange and financial instruments governing it in any form of media that commonly reach a potential investor. How much would a proper understanding of the stock market and its rules affect the portfolio of an average Polish entrepreneur? With this reflection, the author summarizes the attempt to outline the WSE as an institution providing investors with a credible possibility of obtaining profits much larger than those at banks, provided that they are sufficiently involved in understanding information about the exchange, which is relatively new, but also the most rapidly growing opportunity to gain profits in Central and Eastern Europe, with an emphasis also on the added value of being a public company, namely, increased credibility and transparency.

\section{References}

Abdou, K., \& Dicle, M. F. (2007). Do risk factors matter in the IPO valuation? Journal of Financial Regulation and Compliance, 15(1), 63-89.

Altman, E. I. (1968). Financial ratios, discriminant analysis and the prediction of corporate bankruptcy. Journal of Finance, 23(4), 589-609.

Altman, E. I. (2000). Predicting financial distress of companies: Revisiting the Z-Score and Zeta ${ }^{\circledR}$ models. Retrieved from http://pages.stern.nyu.edu/ ealtmanPredFnclDistr.pdf

Altman, E. I., \& Hotchkiss, E. (2005). Corporate financial distress and bankruptcy, predict and avoid bankruptcy, analyze and invest in distressed debt. Hoboken, New Jersey: John Wiley \& Sons, Inc.

Bielawska, A. (2005). Wyjaśnienie trudności nowo powstających przedsiębiorstw w dostępie do kredytów jako przejaw realizacji teorii asymetrii informacji. In A. Bielawska (Ed.), Uwarunkowania rynkowe rozwoju mikro i malych przedsiębiorstw. Mikrofirma 2005 (pp. 437-447). Szczecin: Wydawnictwo Naukowe Uniwersytetu Szczecińskiego.

Bielawska, A. (2001). Podstawy finansów przedsiębiorstwa. Szczecin: Wydawnictwo Zachodniopomorskiej Szkoły Biznesu.

Bień, W. (2008). Rynek papierów wartościowych. Warszawa: Difin.

CSO.(2013). Central Statistical Office. Działalność przedsiębiorstw niefinansowych w 2012 r. Warszawa: CSO.

CSO. (2014). Central Statistical Office. Activity of non-financial enterprises in 2013. Warszawa: CSO.

CSO. (2015). Central Statistical Office. Powierzchnia i ludzkość w przekroju terytorialnym w 2015 r. Warszawa: CSO.

Czapkiewicz, A., \& Wojtowicz, T. (2014). The four-factor asset pricing model on Polish stock market. Economic Research-Ekonomska Istrazivanja, 27(1), 771-783.

Da Gbadji, L. A. G., Gailly, B., \& Schwienbacher, A. (2015). International analysis of venture capital programs of large corporations and financial institutions. Entrepreneurship Theory and Practice, 39, 1213-1245.

Dębski, W. (2014). Rynek finansowy i jego mechanizmy. Warszawa: PWN.

Flores, R., \& Szafarz, A. (1997). Testing the information structure of Eastern European markets: The Warsaw Stock Exchange. Economics of Planning, 30(2-3), 91-105.

Gajdka, J., \& Stos, D. (1996). Wykorzystanie analizy dyskryminacyjnej w ocenie kondycji finansowej przedsiębiorstw. In R. Borowiecki (Ed.), Restrukturyzacja w procesie przekształceń i rozwoju przedsiębiorstw. Kraków: Akademia Ekonomiczna w Krakowie.

Gilson, R. J., \& Black, B. S. (1998). Venture capital and the structure of capital markets: Banks versus stock markets. Journal of Financial Economics, 47, 243-277.

Gompers, P., \& Lerner, J. (2001). The venture capital revolution. Journal of Economic Perspectives, 15(2), 145-168.

Kołosowska, B. (2013). Finansowanie sektora matych i średnich przedsiębiorstw ze źródel pozabankowych. Warszawa: CeDeWu.pl.

Kordela, D. (2013). NewConnect—Rynek giełdowy dla matych i średnich przedsiębiorstw. Warszawa: CeDeWu.pl.

Journal of Laws. (1991). Law on Public Trading in Securities and Trust Funds of March 22, 1991. No. 35, item 155.

Łuczka, T. (2015). Mikroekonomiczne determinanty struktury kapitału w małych i średnich przedsiębiorstwach. Determinanty związane z cechami przedsiębiorstwa. In A. Bielawska (Ed.), Uwarunkowania rynkowe rozwoju mikro, matych i średnich 
przedsiębiorstw. Mikrofirma 2015 (pp. 86-97). Szczecin: Wydawnictwo Naukowe Uniwersytetu Szczecińskiego.

Łuczka, T. (2013). Makro-i mikroekonomiczne determinanty struktur kapitału w malych i średnich przedsiębiorstwach. Poznań: Wydawnictwo Politechniki Poznańskiej.

Małecka, J. (2015a). Giełda Papierów Wartościowych w Warszawie jako potencjalne źródło finansowania małych i średnich przedsiębiorstw. In A. Bielawska (Ed.), Uwarunkowania rynkowe rozwoju mikro, matych i średnich przedsiębiorstw. Mikrofirma 2015 (pp. 496-507). Szczecin: Wydawnictwo Naukowe Uniwersytetu Szczecińskiego.

Małecka, J. (2015b). Economic condition of legal persons in the SME sector-Potential participants of the capital market in Poland. In M. Starnawska (Ed.), Social, innovative and financial dimensions of enterprising organizations (pp. 39-54). Gdańsk: Gdańsk University of Technology.

Małecka, J. (2015c). Selected problems of the capital market in Poland. In M. Postuła and J. Turyna (Eds.), Finansowe uwarunkowania rozwoju organizacji gospodarczych. Zarzqdzanie finansami a efektywność ekonomiczna (pp. 349-362). Warszawa: Wydawnictwo Naukowe Wydziału Zarządzania Uniwersytetu Warszawskiego.

Metrick, A., \& Yasuda, A. (2011). Venture capital and other private equity: A survey. European Financial Management, 17, 619-654.

Mikołajek-Gocejna, M. (2008). IPO jako źródło finansowania rozwoju spółki. Warszawa: SGH w Warszawie-Oficyna Wydawnicza.

Milewski, R. (1998). Podstawy ekonomii. Warszawa: PWN.

Modigliani, F., \& Miller, M. H. (1958). The cost of capital corporation finance and the theory of investment. American Economic Review, 48(3), 261-297.

Mosionek-Schweda, M. (2014). The use of discriminant analysis to predict the bankruptcy of companies listed on the NewConnect market. Equilibrium. Quarterly Journal of Economics and Economic Policy, 9(3), 87-105.

Mrzygłód, U., \& Nowak, S. (2013). Stock exchanges go public. The case of Warsaw Stock Exchange. Journal of International Studies, 6(2), 111-123.

Myers, S. C. (1983). The capital structure puzzle. Journal of Finance, 39(3), 575-592. Papers and Proceedings, Forty-Second Annual Meeting. San Francisco: American Finance Association.

Nawrocki, T., \& Jabłoński, B. (2011). Inwestowanie na rynku akcji. Warszawa: CeDeWu.pl.

Perz, P. (2008). Sztuka inwestowania na GPW. Warszawa: Wydawnictwo K.E.LIBER.

Płókarz, R. (2013). Globalne rynki finansowe. Warszawa: PWN.

Ritter, J. R., \& Welch, I. (2002). A review of IPO activity, pricing, and allocations. The Journal of Finance, 57, 1795-1828.

Robinson, J. (1958). Akumulacja kapitału. Warszawa: PWN.

Vanacker, T., \& Manigart, S. (2013). Venture capital, in alternative investments: Instruments, performance, benchmarks, and strategies. H. K. Baker and G. Filbeck (Eds.). Hoboken, NJ, USA: John Wiley \& Sons, Inc. 